\title{
US Immigration paths for scientific researchers
}

\author{
By Marco Pignone
}

This article is part of a series to run in MRS Bulletin on achieving a path to a green card in the United States. It will cover and compare the criteria for EB-1A classification for foreign nationals of extraordinary ability, EB-1B classification for foreign nationals who are outstanding researchers and professors, and information on the National Interest Waiver category.

\begin{abstract}
A s an immigration lawyer in the United States, I travel to the annual meetings of numerous major scientific organizations and societies, including the Materials Research Society (MRS), to give presentations and provide consultations. Most foreign scientists, from $\mathrm{PhD}$ students to postdoctoral researchers, typically have a poor understanding of their legal immigration situation, regardless of the number of years they have been in the United States.

If you are going to school or working in the United States, and you are not a US citizen or lawful permanent resident ("green card holder"), it is extremely important that you understand the paths that could lead to a green card. You should have a clear timeline so that you understand your situation and know exactly when it will be necessary for you to take action and move forward at each step of the process.

Start by asking yourself what your plans are in the United States. What is your dream job? Is it a tenure-track faculty position or something in industry? If you are
\end{abstract}

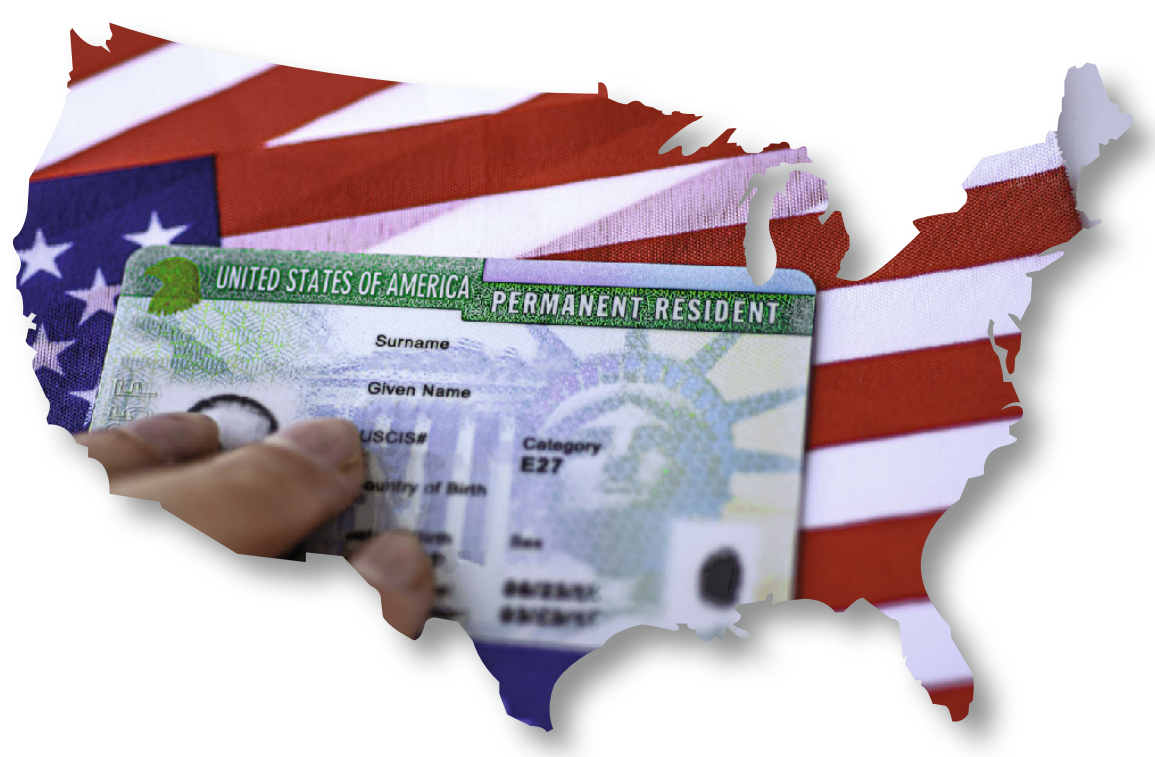

currently a $\mathrm{PhD}$ student, do you want to complete a postdoctoral training program or go straight into industry? Once you have established your short- and long-term goals, you can then start to formulate a plan for your personal immigration timeline.

\section{F-1 student visas and Optional Practical Training}

If you complete a $\mathrm{PhD}$ degree in the United States on an F-1 student visa, it is possible to apply for a green card before you graduate, but for a variety of reasons, it is usually not recommended. Depending on your plans, there may be no benefit to applying early, and few people qualify before graduating. In some cases, it may make sense to take the risk, but as that is relatively rare, I am going to skip over this option.

If you are finalizing and completing a $\mathrm{PhD}$ with an F-1 student visa, your first option after graduation is to obtain work authorization through the Optional Practical Training (OPT) program. Through OPT, you can obtain an
"Employment Authorization Document" or $\mathrm{EAD}$, if you completed a $\mathrm{PhD}$ program in the United States. Generally, a US PhD qualifies you for three years of work authorization through the OPT program.

\section{Obtaining a US green card}

At the end of the OPT, you will need a green card or a work visa to remain in the United States. A green card provides permanent lawful status in the United States and a path to citizenship. To obtain a green card (also known as "lawful permanent resident" status), there are two main paths: 1. EB-1A (Extraordinary Ability) or NIW

(National Interest Waiver) Petitions

2. the Program Electronic Review Management (PERM) labor certification process.

\section{EB-1A and NIW green card petitions}

The EB-1A and NIW paths will be discussed in detail in future articles. The important thing to remember about them for now is that you can "self-petition" or in layman's terms, you can file an application for a green card in these categories without an employer. However, this requires higher qualifications and stricter requirements than the second path, Permanent (PERM) Labor Certification, and not everyone will qualify to self-petition.

\section{PERM Labor Certification}

If you cannot win an EB-1A or NIW case, you will need an employer to help you get a green card. You will need an employer to help because of something referred to as the "labor certification" requirement.

Under US law, to obtain a green card, most workers have to prove that there are no US citizens or green card holders who are already qualified for a particular 
job/position offered by an employer who is willing to file a "labor certification" for you.

Many immigrants are working at jobs where they are the most qualified person for the job. For instance, if you have been working in a particular laboratory or for a particular employer on a certain scientific problem or a particular project, that laboratory or project would obviously suffer if you are forced to leave the United States or if you decide to leave because you are not able to obtain a green card. No one else knows your job as well as you do. The laboratory or company would have to recruit a new employee to replace you, it would delay research projects that you are working on, and in many cases, important research may never be accomplished.

However, US law does not consider these contributions. The law is designed to protect American workers. I disagree with the premise that the law protects American workers, and I think people who are driving scientific research in this country make Americans in general, and specifically Americans who are involved in research, much better off. Many economists will agree with me on this point, but the economics of this issue are not relevant to the decisions that you and your potential employers will be forced to make.

The law says that a company/employer who is willing to file a labor certification for an immigrant worker to help the worker get a green card has to prove that there is "no minimally qualified American worker" for the job.

It is not enough to prove that you are the "best applicant." Rather, you and your employer have to disqualify all other applicants (who are US citizens or green card holders) for the position. In addition, the "minimum qualifications" for the position are often limited by guidelines from the US Department of Labor, and these guidelines often set very low qualifications. If a job requires a particular degree and two years of work experience in the field, then any US citizen or green card holder with the right degree and two years of work experience in the field can jeopardize your PERM case simply by submitting a resume to the employer. If your PERM case fails, then you will not have a path to a green card through your employer, although they can try again in the future and retest the labor market.

\section{PERM case considerations}

In addition to the possibility that labor certification will be denied, there is another important reason why you may want to avoid the PERM process. If an employer filed a PERM case for you, you may be forced to work for that employer for years before you get your green card. If you decide to change jobs during the process, you abandon the PERM case because it belongs to your employer, not to you. The only exception to this, which is rare, is if (1) your PERM labor certification was approved, (2) then you filed your green card application, and (3) you then change jobs more than 180 days after you filed your green card application. In this situation, you can still get your green card even though you no longer work for the petitioning employer that filed your PERM labor certification.

Continue to follow this series of articles in MRS Bulletin. The next article will discuss the two most important work visas, H-1B and $\mathrm{J}-1$, and how they will affect your path to a green card.

Marco Pignone, immigration lawyer at the Philadelphia law firm Getson \& Schatz, P.C., currently focuses on EB-1A and NIW petitions for immigrant researchers. Since 2001, he has represented immigrants in a wide range of immigration matters.

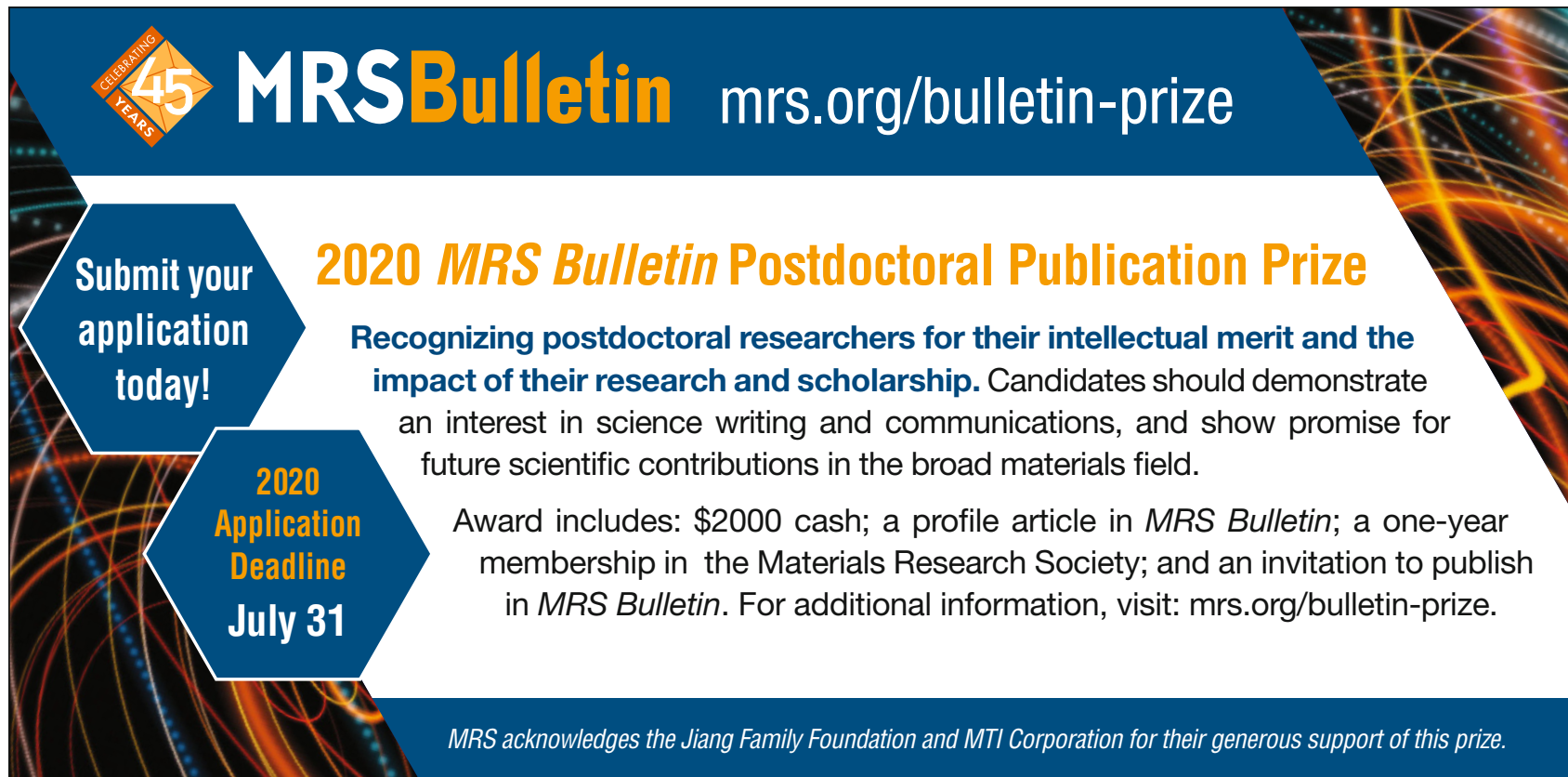

